Małgorzata Korczyńska-Derkacz

Instytut Informacji Naukowej i Bibliotekoznawstwa

Uniwersytet Wrocławski, Wrocław, Polska

malgorzata.derkacz@uwr.edu.pl

ORCID 0000-0002-1470-2252

http://doi.org/10.33077/zbkh.2018.12.korczynska

\title{
Popularyzacja książki rolniczej i czytelnictwa fachowego na wsi a wytyczne IX Plenum KC PZPR (na przykładzie województwa wrocławskiego)
}

\author{
Abstract \\ The popularization of agricultural books and professional \\ reading in the countryside in relation to the $9^{\text {th }}$ Plenary \\ Convention of the Central Committee of the PUWP \\ guidelines (based on Wrocław voivodeship)
}

Bolesław Bierut's paper The task of the party in the struggle to raise the standard of living of working people in the current period of socialist construction presented at the $9^{\text {th }}$ Plenary Convention of the Central Committee of the Polish United Workes' Party (29-30 October, 1953) became the basis for formulating the thesis published prior to II Congress of the PUWP (16 January, 1954). In the struggle for the growth of agricultural production and for the socialist reconstruction of the countryside, the whole society needed to participate; the librarians played an important role in popularizing the agricultural and technical literature. The author enumerated activities and commitments undertaken in this area throughout the country, focusing in particular on the commitments undertaken by public libraries of the Wrocław voivodeship. The basis for the study were archival materials from the Presidium's of the Provincial National Council Department of Culture (1953-1954) available at the State Archives in Wrocław.

Key words: $9^{\text {th }}$ Plenum of the Central Committee of PUWP - methods of propagation of agricultural literature - methods of propagation of technical literature - public libraries of the Wrocław voivodeship (1953-1954) - Competition of Rural Readers (1950-1954) - Bierut Bolesław. 
Słowa kluczowe: IX Plenum KC PZPR - formy upowszechniania literatury rolniczej formy upowszechniania literatury technicznej - bibliotekarstwo publiczne województwa wrocławskiego (1953-1954) - Konkurs Czytelników Wiejskich (1950-1954) - Bierut Bolesław.

IX Plenum KC PZPR odbyło się w Warszawie w dniach 29-30 X $1953 \mathrm{r}$. Zebrani wysłuchali referatu Bolesława Bieruta Zadania partii w walce o szybsze podniesienie stopy życiowej mas pracujacych w obecnym okresie budownictwa socjalistycznego, w którym wskazywał on na „nierozerwalny związek” pomiędzy szybkim wzrostem dobrobytu ludzi pracy a dalszym rozwojem przemysłu, podkreślając zwłaszcza konieczność przyspieszenia wzrostu produkcji rolnej i hodowlanej indywidualnych gospodarstw chłopów oraz przyspieszenie rozwoju socjalistycznych form gospodarki na wsi. W trakcie obrad postanowiono zwołać na 16 I 1954 r. II Zjazd PZPR i przyjąć referat Bieruta jako wytyczne partii przy rozwiązywaniu zadań polityczno-gospodarczych oraz podstawę sformułowania tez przedzjazdowych. Przypominano, że podniesienie stopy życiowej mieszkańców zakładano już w planie sześcioletnim, jednak w trakcie jego realizacji okazało się, iż w latach 1950-1953 zbyt wiele wysiłku pochłonęło - według mówców - usuwanie ,wiekowego zacofania, na jakie Polska była skazana pod rządami obszarników i kapitalistów"1. Dlatego właśnie

Komitet Centralny PZPR stawia jako główne zadanie osiągnięcie w ciągu najbliższych 2 lat [1954-1955] wydatnego wzrostu stopy życiowej ludności pracującej miast i wsi, przyspieszenie w oparciu o dalszy rozwój przemysłu środków wytwórczości tempa wzrostu produkcji rolniczej zarówno roślinnej, jak i zwierzęcej, znaczne podniesienie produkcji przemysłu artykułów konsumpcyjnych przy równoczesnym podniesieniu jakości i wzbogaceniu jej asortymentu oraz znaczny rozwój budownictwa mieszkaniowego dla ludzi pracy². Za podstawę dyskusji przedzjazdowych przyjęto dwie tezy:

1. „Osiągnięcia w wykonaniu Planu Sześcioletniego i główne zadania gospodarcze w latach 1954-1955” oraz 2. „O zadaniach rozwoju rolnictwa w latach 1954-1955 i o zapewnieniu niezbędnych środków dla wzrostu produkcji rolniczej"3.

W szerokiej analizie możliwości stojących przed poszczególnymi organami administracji państwowej i organizacjami partyjnymi w walce o wzrost produkcji rolnej podkreślano m.in., iż do zadań Ministerstwa Rolnictwa i Państwowych Gospodarstw Rolnych (PGR) należeć będzie rozszerzenie zasięgu

${ }^{1}$ Zadania partii $w$ walce o szybsze podniesienie stopy zyciowej mas pracujacych w obecnym okresie budownictwa socjalistycznego. Referat przewodniczacego KC PZPR towarzysza Bolestawa Bieruta wygloszony na IX Plenum KC PZPR, „Nowe Drogi” 1953, nr 10, s. 40. Cały numer został poświęcony IX Plenum.

2 Tamże, s. 41.

3 Tamże, s. 5. 
propagandy rolniczej, działalności odczytowo-propagandowej, kursów upowszechniania wiedzy rolniczej, organizowania wystaw, wydawanie ulotek, afiszy, zakładanie poletek pokazowych. Określając zadania organizacji partyjnych stwierdzano, że „Nauczyciele, pracownicy służby zdrowia, agronomowie, zootechnicy, mechanizatorzy i pracownicy instytucji kulturalnych [podkr. MK-D] powinni odegrać poważną rolę w walce o wzrost produkcji rolniczej i o socjalistyczną przebudowę wsi"

Przedmiotem szkicu jest działalność bibliotek w odniesieniu do czytelnika wiejskiego, którego należało zainteresować czytelnictwem i książką, w szczególności książką rolniczą. W artykule przedstawiono formy popularyzacji książki fachowej i czytelnictwa, realizowane przez biblioteki na terenie województwa wrocławskiego.

Źródłem do analizy udziału bibliotek wiejskich w realizacji wytycznych IX Plenum KC PZRR były materiały archiwalne zgromadzone w Archiwum Państwowym we Wrocławiu, w zespole Prezydium Wojewódzkiej Rady Narodowej (WRN), Wydział Kultury IX/25. Zespół obejmuje 106 kart będących sprawozdaniami z przebiegu realizacji: uchwały egzekutywy KW PZPR dotyczącej pracy kulturalnooświatowej na wsi dolnośląskiej, wytycznych IX Plenum i tez przedzjazdowych, wytycznych w sprawie zadań na odcinku poprawy warunków bytowych klasy robotniczej w latach 1953-1955, uchwał w sprawie zadań rozwoju rolnictwa w latach 1954-1955, zawiera też sprawozdania z bibliotek gminnych, zarządów gminnych Związku Samopomocy Chłopskiej i świetlic. Drugą grupę źródeł stanowiły teksty publikowane ówcześnie na łamach „Poradnika Bibliotekarza”, których autorami byli działacze Stowarzyszenia Bibliotekarzy Polskich (SBP), urzędnicy ministerialni, kierownicy Centralnego Zarządu Bibliotek (CZB).

\section{Oczekiwania partii i rządu wobec bibliotekarzy}

W sytuacji, gdy cały kraj przystąpił do podejmowania dodatkowych ,zobowiązań produkcyjnych", mających związek z postawionymi przez partię zadaniami, można się zastanawiać nad charakterem zobowiązań podejmowanych przez pracowników kultury, w tym bibliotekarzy. Jasno sformułował je wiceminister kultury i sztuki Stanisław Piotrowski na Zjeździe Delegatów SBP, który obradował w Warszawie w dniach 19-20 XII 1953 r. ${ }^{5}$ Minister stwierdził wówczas, iż mieszczą się one:

w ogólnych zadaniach ubojowienia [!] i usprawnienia pracy, zwiększania wydajności przez włączanie się do bieżących zadań społeczeństwa, troski o oszczędną gospodarkę

4 Tamże, s. 97.

5 Stowarzyszenie Bibliotekarzy Polskich, „Bibliotekarz” 1954, nr 1, s. 1-2. 
w bibliotekach. Ubojowienie pracy bibliotekarza - to świadome działanie, aby wypożyczane książki przyczyniały się do wzrostu świadomości społecznej środowiska, to propagowanie literatury marksistowskiej, światopoglądowej, fachowej i pięknej, to wyjaśnianie i propagowanie zadań, jakie stawia Partia i Rząd. Usprawnienie pracy - to nie tylko usprawnienie maszynerii wewnątrzbibliotecznej, ale również wyjście na spotkanie czytelnika, a w bibliotekach powszechnych - to wyjście do czytelnika i po czytelnika. Jeśli obecnie głównym zadaniem narodu, w pierwszym rzędzie chłopów, jest walka o podniesienie produkcji rolnej, jako jednego z warunków zapewniających wzrost dobrobytu mas pracujących, to biblioteki w tej walce mogą dać i już podają do ręki producenta skuteczny oręż. Orężem tym jest książka rolnicza.

Minister podkreślił, że zadania te stoją w równej mierze przed punktami bibliotecznymi na wsi, jak i przed bibliotekami gminnymi, powiatowymi, wojewódzkimi. Wskazał też na biblioteki naukowe, które powinny włączyć się w nurt prac przygotowując odpowiednio opracowane bibliografie oraz wskazówki metodyczne i instrukcyjne. Zwrócił uwagę na trwający właśnie IV etap Konkursu Czytelników Wiejskich, wielkiej masowej imprezy, w której w tej chwili bierze udział ponad 500 tysięcy zgłoszonych uczestników, chłopów. [...] czy może bibliotekarz spokojnie przechodzić obok tego doniosłego zjawiska rewolucji kulturalnej na wsi, jaka się dokonuje na naszych oczach?6.

Wychodząc naprzeciw oczekiwaniom władzy, uczestnicy Walnego Zjazdu Delegatów SBP wystosowali list do B. Bieruta, w którym deklarowali:

Dołożymy starań, aby biblioteki przez upowszechnienie czytelnictwa spełniły jak najlepiej swoją rolę w tym epokowym przełomie, jakiego dokonuje nasz naród pod przewodnictwem Partii i Rządu, przekształcając Polskę z zacofanego i ubogiego kraju rolniczego w bogaty kraj nowoczesnego przemysłu i rolnictwa. Szczególnie ważne zadanie widzimy w rozwijaniu aktywności kulturalnej wsi, we współdziałaniu z rozwojem spółdzielczości produkcyjnej, w usuwaniu ciemnoty i zacofania przez współudział w akcji szerzenia wiedzy rolniczej i lepszego wykorzystania literatury rolniczej ${ }^{7}$.

W liście podpisanym przez Prezydium Zarządu w składzie: dr Aleksander Birkenmajer, Władysław Bieńkowski, Jan Baumgart, Stefan Kotarski, SBP deklarowało także, że zrzeszeni w nim bibliotekarze bibliotek wszystkich typów dołożą starań w popularyzacji literatury radzieckiej, pogłębianiu przyjaźni polsko-radzieckiej i upowszechnianiu dorobku bibliotek ZSRR i krajów demokracji ludowej.

${ }^{6}$ Odpowiedzialne zadania bibliotekarzy polskich po IX Plenum KC PZPR. Przemówienie Wiceministra Kultury i Sztuki Stanistawa Piotrowskiego na Zjeździe Delegatów SBP w dniu 19 grudnia 1953 r., „Bibliotekarz” 1954, nr 1, s. 3-4.

7 List Walnego Zjazdu Delegatów SBP do Prezesa Rady Ministrów Bolesława Bieruta, „Bibliotekarz” 1954, nr 1, s. 2-3. 


\section{Bibliotekarze w ogólnonarodowym czynie przedzjazdowym - działania i zobowiązania}

\section{Żywiołowo włączali się bibliotekarze do wielkiego ogólnonarodowego czynu przedzjazdo-} wego podejmując szereg zobowiązań, które powinny przyczynić się do pogłębienia pracy bibliotekarza nad upowszechnieniem książki i prasy jako poważnego czynnika w podnoszeniu świadomości mas pracujących oraz pomocy w zwiększaniu wydajności pracy, podnoszeniu kwalifikacji zawodowych i przyspieszeniu realizacji zadań postawionych przed światem pracy przez IX Plenum KC PZPR

czytamy w sprawozdaniu z dyskusji przedzjazdowych na stronach „Poradnika Bibliotekarza"8, w którym redakcja przedstawiała też sposoby i środki wykorzystywane przez aktywnych bibliotekarzy, aby w ten sposób pomóc tym, którzy takiej dyskusji jeszcze nie podjęli ${ }^{9}$.

Jak podkreślano, najważniejszą sprawą były tezy i ich szeroka popularyzacja - tu liczył się każdy pomysł. Proponowano zakładanie specjalnych teczek, w których zbierane by były materiały dotyczące tez i uchwał IX Plenum oraz referatu Bieruta. Gromadzone wycinki prasowe z artykułami, dotyczącymi podejmowanych przez świat pracy zobowiązań, należało udostępniać czytelnikom oraz aktywistom i działaczom partyjnym prowadzącym przedzjazdowe dyskusje. Tym ostatnim należało także przygotowywać niezbędne w ich pracy książki, ,aby biblioteka była stałą pomocą w ich działalności”. Natomiast prelegenci Towarzystwa Wiedzy Powszechnej i Uniwersytetów Wiedzy Rolniczej powinni wskazywać zebranym na odczytach, że książki dostarczane przez bibliotekę stanowią naturalne przedłużenie pracy nad rozwijaniem i pogłębianiem tematu poruszonego w odczycie, ponieważ „Współpraca ta musi się bardzo zacieśnić jeśli chcemy skutecznie realizować wskazania IX Plenum"10. Biblioteka, wraz z organizacjami masowymi i świetlicami, miała tworzyć punkty konsultacyjne dla miejscowej ludności.

Bardzo ważne było objęcie programem rozwoju czytelnictwa książek o tematyce polityczno-społecznej, rolniczej, technicznej oraz prasy jak najszerszego grona mieszkańców wsi. Akcja skierowana była do mało- i średniorolnych chłopów, członków spółdzielni produkcyjnych, pracowników PGR-ów, Państwowych i Gminnych Ośrodków Maszynowych (POM i GOM), inteligencji wiejskiej, aktywu gromad i gmin. Jako stałych czytelników biblioteki starały się pozyskać agronomów, techników, traktorzystów, pracowników rad narodowych, działaczy partyjnych i społecznych, aktywistów ZSCh (Związku Samopomocy Chłopskiej), ZMP

\footnotetext{
Bibliotekarze w dyskusjach przedzjazdowych, „Poradnik Bibliotekarza” 1953, nr 12, s. 268.

Tamże, s. 265-272; Nasze zadania na tle IX Plenum, tamże, 1954, nr 1, s. 1-6.

10 Nasze zadania na tle..., s. 5-6.
} 
(Związku Młodzieży Polskiej). Pamiętano i o kobietach. Potencjalnych czytelników należało zachęcić do odwiedzania biblioteki, która w gminie czy gromadzie stać się miała miejscem spotkań z delegatami na II Zjazd Partii, dyskusji nad książkami utrwalającymi w nich wiedzę o sojuszu robotniczo-chłopskim, o dobrobycie, do którego droga wiodła przez wzrost produkcji rolnej i hodowlanej. Wskazywano na konieczność prowadzenia przemyślanych działań propagandowych, zwłaszcza wobec książki rolniczej, która odpowiednio dobrana i „we właściwym momencie podsunięta” jest warunkiem realizacji tez i wytycznych IX Plenum. Chętnie przytaczano pozytywne przykłady wskazujące na praktyczne wykorzystanie wiedzy rolniczej, na jej wpływ na podniesienie wydajności z hektara, osiągnięcie lepszych wyników w hodowli lub zmianę własnych kwalifikacji, jak np. „jeden z czytelników zaczął się dokształcać w zakresie wiedzy rolniczej, a wreszcie ukończył krótki kurs z dziedziny weterynarii i obecnie jest weterynarzem gromadzkim" ${ }^{11}$. Nie tak dobrze było z książką o charakterze politycznym i z prasą. Popularyzację tej ostatniej oceniano na ogół najgorzej, podkreślając, że prasa powinna być - a nie jest - stale obecna w działaniach propagandowych. W celu poprawienia sytuacji proponowano organizowanie „głośnego czytania gazet w polu w czasie żniw”"12.

Przypominano bibliotekarzom, żeby pamiętali o takim doborze literatury pięknej, w której „w sposób porywający ukaże [się] piękno i urok pracy na wsi”"13. Zagadnienie było bardzo istotne, ponieważ młodych ludzi trzeba było zachęcić do pozostania na gospodarstwie, pokazać im, że mechanizacja rolnictwa daje szansę zdobycia nowych zawodów: traktorzysty, mechanika w GOM-ie, agronoma, zootechnika. Często podkreślano też, że dorosły człowiek idzie do biblioteki niechętnie, trafia do niej z obowiązku, ponieważ - nie będąc z książką zaznajomiony - „nie czuje jej głodu”. Może do niej jednak trafić za pośrednictwem dzieci, które w ten sposób stają się istotnym ogniwem walki o lepsze jutro; dla najmłodszych trzeba zatem stworzyć w bibliotece odpowiednie warunki, zapewnić im wartościowy księgozbiór. Pomocą dla bibliotekarzy w zakresie upowszechniania wiedzy polityczno-społecznej i rolniczej miał się też stać IV etap Konkursu Czytelników Wiejskich ${ }^{14}$. Przypomnijmy tu krótko, że został on zapoczątkowany w latach 1950-1951 przez ZSCh i był następnie kontynuowany przez organizacje masowe i instytucje kulturalno-oświatowe. Współpracowały i były współodpowiedzialne za

\footnotetext{
11 Tamże.

12 Tamże, s. 5.

13 Tamże, s. 2.

14 Interesująco na temat konkursu pisze Dariusz Jarosz, Codzienna mobilizacja. O propagandzie czytelnictwa książek w Polsce stalinowskiej i trudnościach jej badania, „Z Badań nad Książką i Księgozbiorami Historycznymi” 2011, t. 5, s. 295-305.
} 
jego organizację i przebieg przede wszystkim: Rada Czytelnictwa i Książki, Ministerstwo Kultury i Sztuki, CZB oraz Zarząd Świetlic, Domów Kultury i Twórczości Amatorskiej, Departament Upowszechniania Wiedzy Rolniczej oraz Departament Spółdzielczości Produkcyjnej w Ministerstwie Rolnictwa, Centralny Zarząd POM, ZSCh, ZMP, Powszechna Organizacja „Służba Polsce", Ludowe Zespoły Sportowe, Związek Zawodowy Pracowników Rolnych, Związek Zawodowy Nauczycielstwa Polskiego, Związek Literatów Polskich, Związek Zawodowy Pracowników Kultury, Towarzystwo Przyjaźni Polsko-Radzieckiej, Liga Kobiet, Straż Pożarna, Centralny Urząd Wydawnictw, Centrala Rolnicza Spółdzielni „Samopomoc Chłopska”. Mając na uwadze upowszechnianie wśród pracujących chłopów czytelnictwa współczesnej literatury beletrystycznej, popularnonaukowej oraz postępowej literatury dawniejszej konkurs miał się przyczynić do:

podniesienia i pogłębienia świadomości politycznej uczestników konkursu, kształtowania ich światopoglądu na naukowych podstawach marksizmu-leninizmu, pogłębienia uczuć patriotyzmu do Polski Ludowej, przyjaźni do narodów Związku Radzieckiego, krajów Demokracji Ludowej oraz mas pracujących świata, walczących o pokój, zaostrzenia czujności chłopstwa pracującego na wrogą i szkodliwą dla państwa ludowego działalność wrogów Polski Ludowej, do rozumienia polityki partii i władzy ludowej, uaktywnienia uczestników w realizowaniu w codziennej pracy zadań wynikających z Planu 6-letniego i założeń Frontu Narodowego dla umocnienia siły ojczyzny ludowej i utrwalenia pokoju oraz pomóc im w:

podnoszeniu produkcji rolnej, stosowaniu ulepszeń w uprawie i hodowli, organizowaniu i umacnianiu spółdzielczości produkcyjnej, rozwijaniu życia kulturalnego gromady, pełnym i świadomym uczestniczeniu w pracach terenowych organów władzy ludowej, wykonywaniu obowiązków wobec państwa ${ }^{15}$.

Konkurs adresowany był do chłopów, zwłaszcza tych, którzy do tej pory nie czytali. Wykluczono udział uczniów szkół podstawowych. Należało tylko wypełnić formularz zgłoszeniowy lub wpisać się na listę odpowiedniego zespołu czytelniczego oraz przeczytać pięć książek z wykazu konkursowego, w tym przynajmniej dwie popularnonaukowe ${ }^{16}$. Na zgłoszeniu trzeba było podać tytuły wybranych książek. Można było korzystać ze zbiorów wszystkich bibliotek publicznych i społecznych na danym terenie (biblioteka gminna, punkt biblioteczny, PGR, POM, spółdzielnia produkcyjna, ZSCH, itp.) oraz z książek własnych. Dla ułatwienia nabywania potrzebnych pozycji sklepy Gminnej Spółdzielni (GS) i punkty sprzedaży miały być odpowiednio zaopatrzone. Zgłoszenia przyjmowała Gromadzka Komisja Konkursowa

15 Konkurs Czytelników Wiejskich IV etapu: 22.VII.1953-22.VII.1954, „Poradnik Bibliotekarza" 1953, nr 9, s. 198-199.

16 R. Łukaszewska, Jak dobierać książki do czytania w Konkursie Czytelników Wiejskich, „Poradnik Bibliotekarza” 1953, nr 11, 241-251. 
i przekazywała je do Gminnej Komisji Konkursowej, ta dalej - przez komisje powiatowe i wojewódzkie - do komisji centralnej przy CZB. W ramach konkursu organizowano współzawodnictwo na wszystkich szczeblach (gmina, powiat, województwo, pomiędzy placówkami kulturalno-oświatowymi, placówkami społeczno-gospodarczymi oraz pomiędzy aktywistami - nauczycielami, organizatorami). Przy ocenie współzawodnictwa brano pod uwagę sukcesy w zaangażowaniu początkujących czytelników, absolwentów nauczania początkowego oraz kobiet, a na tzw. „Ziemiach Zachodnich” - ludności rodzimej. Pomoc metodyczną zapewniały: Centralny Ośrodek Metodyczny Zarządu Świetlic, Domów Kultury i Twórczości Amatorskiej.

Kolejnym etapem było wypełnienie ankiety składającej się z siedmiu pytań, z których trzy pierwsze dotyczyły lektury („,co było najbardziej interesujące, co można by zastosować w życiu, którą z książek chciałbyś mieć na własność?"), pytania 4-5 stanowiła metryczka czytelnika, w 6 - pytano o tytuły przeczytanych książek, a w 7 - o członków zespołów czytelniczych. Przewidziano nagrody dla czytelników, kierowników, organizatorów zespołów czytelniczych i dla samych zespołów. Zdobyć można było Odznakę „Przodownika Czytelnictwa” III, II lub I stopnia.

Na II Krajowym Zlocie Przodowników Czytelnictwa w Warszawie w dniach 30-31.V.1953 r. postanowiono prowadzić nadal konkurs czytelników bibliotek wiejskich i objąć nim w IV etapie pół miliona chłopów pracujących. W liście do Prezesa Rady Ministrów Bolesława Bieruta uczestnicy Zlotu przyrzekli, że nie będą szczędzić wysiłku, że zdobędą się na najwyższy trud, by pogłębiać rewolucję kulturalną na wsi, by przez książkę i oświatę podnosić poziom kulturalny mas chłopskich [...] by książka stała się powszechnym chłopskim orężem walce o nową, postępową wieś, w walce o pokój i socjalizm ${ }^{17}$.

Złożone zobowiązanie uczestników Zlotu spowodowało, że dyrektor CZB Władysław Jagusztyn skierował do bibliotekarzy „budzący zapał i entuzjazm” list, w którym pisał m.in.:

Kiedyś w Polsce sanacyjnej raporty policyjne donosiły siedzącym u władzy wyzyskiwaczom, że «najniebezpieczniejsi są ci, którzy dużo czytają». Dziś Państwo ludowe swą siłę, swój postęp opiera o rosnącą świadomość robotników, chłopów i inteligencji pracującej, dba o podniesienie kultury i oświaty mas pracujących, o rozwój czytelnictwa. [...] Wspólnym wysiłkiem [...] dźwigamy nasz kraj z zacofania, przeobrażamy z kraju rolniczego na kraj przemysłowo-rolny. [...] IX Plenum [...] w oparciu o dotychczasowe osiągnięcia postawiło zadanie szybszego podniesienia dobrobytu ludzi pracy miast $i$ wsi. Przyspieszenie walki o nową wieś, wieś postępu i dobrobytu, nowoczesnej kultury rolnej, w wieś wysokich urodzajów - to realizacja zadań postawionych przez Partię i Rząd. Osiągnąć to potrafią ludzie rozumiejący nowe życie, umiejący korzystać z nowych narzędzi i stosować nowoczesne metody uprawy roli i hodowli. Pomocą im w tym będzie właściwa książka.

17 Bibliotekarze w dyskusjach..., s. 269. 
[...]. Wy musicie troszczyć się oto, aby książka nie leżała bezczynnie w bibliotece, aby znalazła się w rękach młodzieży, w rękach chłopów pracujących. [...] Stoicie na wysuniętym odcinku walki o pogłębienie rewolucji kulturalnej na wsi, walki z ciemnotą i zabobonem o rzetelną wiedzę i wysoką kulturę mas chłopskich ${ }^{18}$.

Wobec uchwał IX Plenum na IV etapie Centralna Komisja Konkursu Czytelniczego opracowała instrukcję, stanowiącą wytyczne dla wszystkich organizatorów konkursu, a wiec także dla bibliotekarzy.

Bardzo ważną dziedziną pracy bibliotek, często wskazywaną wśród możliwych form podejmowanych zobowiązań związanych z przygotowaniami do II Zjazdu PZPR, były wystawy książek organizowane na podstawie materiałów bibliograficznych opracowanych przez wojewódzkie biblioteki publiczne, a dotyczące ,kierowniczej roli Partii w budowaniu państwa socjalistycznego, historii Partii, sojuszu robotniczo-chłopskiego, dotychczasowych osiągnięć Polski Ludowej w dziedzinie politycznej, gospodarczej i kulturalnej"19. Wymieniano szczególnie aktywnych bibliotekarzy, którzy przy okazji takich wystaw przedstawiali stan czytelnictwa na własnym terenie, zwracali uwagę na jego znaczenie jako ,poważnego czynnika w podnoszeniu aktywności politycznej i produkcyjnej mas pracujących"20. Ponieważ wzrost wypożyczeń literatury polityczno-społecznej był na ogół niewielki, bo wykorzystywali ją przede wszystkim ludzie poszukujących materiałów do szkolenia lub młodzież szkolna, zdarzały się i głosy krytyczne, w których dotychczasowy wysiłek był określony jako niewystarczający.

Wśród możliwych do realizacji zadań, wymieniano organizowanie kolejnych punktów bibliotecznych, gdyż ,każdy z kolegów bibliotekarzy gminnych musi poddać analizie sieć punktów bibliotecznych w swojej gminie i nakreślić racjonalny plan działania w tym zakresie" 21 . Zachęcano do podejmowania indywidualnych zobowiązań, podając na łamach czasopisma konkretne przykłady, np. kierowniczki Gminnej Biblioteki w Żurawinie, Ireny Litki, która postanowiła, m.in.:

do 17 stycznia 1954 roku osiągnąć 16\% stałych czytelników w stosunku do ogółu ludności gminy, [...] zwiększyć ilość wypożyczeń książki technicznej i fachowej o 15\% ogółu wypożyczeń, [...] zorganizować kolejne punkty biblioteczne, na IV etapie Konkursu Czytelników Wiejskich zwerbować 10\% ludności gminy oraz propagować referat i tezy

II Zjazdu w pracy z książką wśród uczestników konkursu.

Podejmując zobowiązania bibliotekarka wyraziła też pogląd, że: ,przyspieszenie rewolucji kulturalnej na terenie wsi - zależy w głównej mierze od pracy bibliotekarzy"22.

\footnotetext{
18 W. Jagusztyn, Koleżanko! Kolego!, „Poradnik Bibliotekarza” 1953, nr 12, s. 269-272.

19 Bibliotekarze $w$ dyskusjach..., s. 266.

20 Tamże.

$21 \quad$ Nasze zadania na tle..., s. 4.

22 Bibliotekarze $w$ dyskusjach..., s. 268.
} 


\section{Bibliotekarze województwa wrocławskiego wobec zadań przedzjazdowych}

W czerwcu 1953 r. Prezydium WRN we Wrocławiu w planach na III i IV kwartał tego roku w zakresie polityki kulturalno-oświatowej zakładało realizację trzech grup tematycznych, określając je dość ogólnie jako:

- przygotowanie do akcji kulturalno-oświatowej na okres jesienno-zimowy,

- rola nauczyciela i świetlicy w podniesieniu produkcji rolnej,

- praca kulturalna na wsi ${ }^{23}$.

Według danych dotyczących Biblioteki Wojewódzkiej, zamieszczonych w „Sprawozdaniu z przebiegu realizacji uchwał egzekutywy KW. z dnia 6.VI. 1953 roku dot. pracy K.O. na wsi" posiadała ona w połowie $1953 \mathrm{r}$. w swym pionie: 26 bibliotek powiatowych, 5 bibliotek miejskich w miastach wydzielonych (w tym 38 filii i 4 filie dla dzieci), 57 bibliotek miejskich, 221 bibliotek gminnych (w tym 1583 punkty biblioteczne i 39 specjalistycznych) oraz 388 bibliotek ruchomych. Zbiory Biblioteki Wojewódzkiej szacowano na 21115 egzemplarzy, a w całym województwie - 1421890 tomów. W tym samym roku na terenie województwa wrocławskiego biblioteki wypożyczyły 4373041 tomów. Czytelników na dzień 31 XII 1953 r. było $193760^{24}$.

Jak wynika z cytowanego Sprawozdania w bibliotekach terenowych dawał się odczuć poważny brak literatury fachowej w zakresie rolnictwa. Wprawdzie instruktorzy Biblioteki Wojewódzkiej docierali do bibliotek powiatowych, a czasem nawet do gminnych, to jednak nie mieli oni bezpośredniego kontaktu z czytelnikiem:

W wielu wypadkach bibliotekarze gminni stosują właściwe metody pracy z czytelnikiem, w wyniku czego przeczytane książki [...] wpływają na zmianę psychiki człowieka wiejskiego, na zrozumienie dokonywanych przemian w Polsce Ludowej, przyczyniają się do podnoszenia wydajności plonów przez właściwe stosowanie form agrotechnicznych. Za przykład może służyć biblioteka w gminie Wińsku i ob. Sulikowski, który funkcje bibliotekarza pełni już przez 5 lat sam. W wyniku przeczytanych książek fachowych z zakresu rolnictwa wziął działkę 10 ar., uprawił kukurydzę jako poletko doświadczalne mobilizując w ten sposób okolicznych chłopów i mieszkańców gminy i wykazując im słuszność nowych sposobów - nowych metod uprawy. W Kątach Wrocławskich kier. Biblioteki ob. Urbaniak Eugenia przed prelekcją U[uniwersytetu] W[iedzy] R[rolniczej] zorganizowała

23 Archiwum Państwowe we Wrocławiu (APWr.), PWRN, Wydział Kultury, sygn. IX/25, Sprawozdanie z przebiegu realizacji uchwał egzekutywy KW z dn. 6.VI.1953 roku dot. pracy K.O. na wsi. Prezydium W.R.N. Wydział Kultury i Biblioteki Wojewódzkiej, k. 24; Bibliotekarze w dyskusjach..., s. 268.

24 Archiwum Państwowe we Wrocławiu APWr., PWRN, Wydział Kultury, sygn. IX/25, Sprawozdanie z przebiegu realizacji uchwał egzekutywy KW. z dnia 6.VI.1953 roku..., k. 24-29. 
wystawę książki rolniczej. Po prelekcji chłopi zaradzali [sic!] sprzedaży tej książki. Jednakowoż w/w zaproponowała wypożyczenie tych książek, co spotkało się z ogólnym zadowoleniem. W wyniku właściwej pracy gminnych bibliotek chłop, czytelnik przyswaja sobie nowe metody uprawy roli stosując siewniki, żniwiarki, pociągając za sobą innych nie przekonanych jeszcze chłopów ${ }^{25}$.

Jak wynika z opinii instruktorów, ulubionymi pisarzami, cieszącymi się wielką poczytnością w bibliotekach województwa wrocławskiego byli twórcy rosyjscy: Maksym Gorki, Aleksandr Fadiejew, Nikołaj Ostrowski, Lew Tołstoj, Anton Makarenko, a z pisarzy polskich: Bolesław Prus, Eliza Orzeszkowa, Józef Ignacy Kraszewski, Henryk Sienkiewicz.

4 XII 1953 r. Prezydium WRN we Wrocławiu podjęło uchwałę nr 21/53 w sprawie zadań na odcinku poprawy warunków bytowych klasy robotniczej w latach 1953-1955²6, będącą już bezpośrednią reakcją na postanowienia IX Plenum. Uchwała nakładała na pracowników Wydziału Kultury obowiązek „,podwojenia [...] pracy polityczno-organizacyjnej ze strony wszystkich [...] podległych placówek, czynnego upowszechnienia kultury". Odpowiedzią na nią był „Plan zabezpieczenia wykonania zadań wynikających z Uchwały IX Plenum i tez przedzjazdowych PZPR"27, w którym zamieszczone zostały szczegółowe wskazówki pracy dla zespołów świetlicowych, agitatorów, jak też opisane zasady i formy upowszechniania wiedzy rolniczej, amatorskiego i zawodowego ruchu artystycznego.

Odnośnie do bibliotek zakładano:

1. Popularyzację referatu tow. Bieruta i tez na II Zjazd Partii, kontrolę realizacji zobowiązań na cześć II Zjazdu poprzez:

a) organizowanie i prowadzenie kółek samokształceniowych przy terenowych bibliotekach, pomoc przy prowadzeniu zajęć tych kółek, organizowanych przez inne organizacje i instytucje. Referat bibliotek przewiduje prace w 50 kołach samokształceniowych w pierwszym kwartale br. [1954].

b) opracowanie gazetek ściennych, plansz i wykresów z dziedziny wzrostu czytelnictwa literatury fachowej po jednej gazetce w każdej bibliotece terenowej.

2. Większe niż dotychczas powiązanie pracy bibliotek terenowych z pracą świetlic przez:

a) czynny udział pracowników bibliotek w prowadzeniu zajęć w kołach samokształceniowych, Wszechnicy radiowej, organizowaniu pogadanek, odczytów itp.

3. W pracy z książką przeprowadzić około 2000 zajęć z czytelnikiem organizując:

a) wieczory literackie, autorskie, żywego słowa. Na każdą bibliotekę gminną przewidujemy 4 imprezy tego rodzaju rocznie.

25 Tamże, k. 28-29.

26 Tamże, Sprawozdanie z realizacji uchwały Nr.21/53 Wojewódzkiej Rady Narodowej z dnia 4 grudnia $53 \mathrm{r}$. w sprawie zadań na odcinku poprawy warunków bytowych klasy robotniczej w latach 1953-1955, k. 35-41.

27 Tamże, k. 42. 
4. Przedstawiając czytelnictwo w formach plastycznych biblioteki terenowe zorganizują na przestrzeni 1954 i 1955 r.:

a) 2500 wystawek okolicznościowych książek; szczególne nasilenie pójdzie w miesiącach maj, czerwiec (Dni OKP Dni Oświaty Książki i Prasy)

5. W dziedzinie troski o podniesienie kultury i rozwój czytelnictwa na wsi biblioteki terenowe poczują się w pełni odpowiedzialne za przebieg IV etapu Konkursu Czytelników Bibliotek Wiejskich.

a) Otoczą opieką uczestników zgłoszonych w konkursie w/w, udzielając im pomocy w składaniu wypowiedzi na temat przeczytanych książek.

b) Pracownicy bibliotek dopomogą w przeprowadzeniu zajęć zespołów czytelniczych w gromadach ${ }^{28}$.

Wymieniony w punkcie piątym i wspomniany już wyżej konkurs skupiał bardzo dużo uwagi i wielokrotnie powracano do niego zarówno w planach, jak i uchwałach. W województwie wrocławskim, jak czytamy w ,Sprawozdaniu z realizacji uchwały Nr. 21/53 Wojewódzkiej Rady Narodowej z dnia 4 grudnia 53 r.”:

Terenowe biblioteki publiczne skupiły wokół przebiegającego Konkursu Czytelników Bibliotek Wiejskich 42.143 uczestników pracujących w 1445 zespołach czytelniczych;

17.615 uczestników z pozostałych 24.538 zgłoszeń to czytelnicy indywidualni ${ }^{29}$.

Szczegółowy plan pracy bibliotek województwa wrocławskiego, który miał być zrealizowany do końca IV kwartału 1953 r., przedstawia tab. 1.

$\mathrm{Z}$ analizy planu wynika, iż łączna liczba zaplanowanych wydarzeń była bliska 3600. W zakresie czytelnictwa i upowszechniania wiedzy rolniczej założono zorganizowanie: 283 wieczorów dyskusyjnych, tematycznych wystaw książek połączonych z konkursami, wieczorów żywego słowa poświęconych wierszom Władysława Broniewskiego oraz utworzenie 568 nowych bibliotek sąsiedzkich i powołanie 1136 księgonoszy. Dodatkowe dane podaje tzw. plan cyfrowy (zob. Aneks 1), według którego zakładano też organizowanie propagandy wzrokowej poświęconej akcji siewnej, żniwnej i obowiązkowym dostawom. Planowano wydanie ok. 880 „,błyskawic”, czyli krótkich, aktualnych tekstów zamieszczanych na tablicach ogłoszeń, co dawało średnio dwie ,błyskawice" rocznie w każdej Gminnej Bibliotece Publicznej. Błyskawice miały piętnować wszelkie niedociągnięcia i ,przejawy wrogiej roboty”.

„Sprawozdanie Prezydium Wojewódzkiej Rady Narodowej z działalności placówek kulturalno-oświatowych na terenie wojew. wrocławskiego" datowane na 23 I 1954 r. zaopatrzono w szczegółowy plan pracy dla Biblioteki Wojewódzkiej w okresie od 30 XI 1953 r. do końca I kwartału 1954 r. (tab. 2).

28 Tamże, k. 46-47.

29 Tamże, Sprawozdanie z realizacji uchwały Nr.21/53..., k. 38. Na temat konkursu zob. D. Jarosz, dz. cyt. 
Popularyzacja książki rolniczej i czytelnictwa fachowego na wsi

\begin{tabular}{|c|c|c|c|c|c|c|c|}
\hline \multirow{5}{*}{ 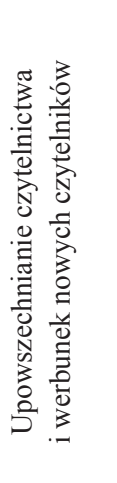 } & \multicolumn{2}{|c|}{ 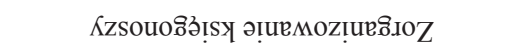 } & i & in & 寸 & ñ & 晃 \\
\hline & \multicolumn{2}{|c|}{ 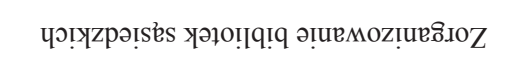 } & $\infty$ & $\stackrel{\sim}{\sim}$ & ป & $\stackrel{0}{-}$ & $\stackrel{\infty}{-}$ \\
\hline & \multicolumn{2}{|c|}{ 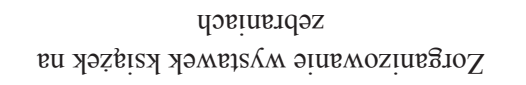 } & $a$ & 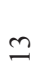 & $=$ & $\infty$ & $a$ \\
\hline & \multicolumn{2}{|c|}{ 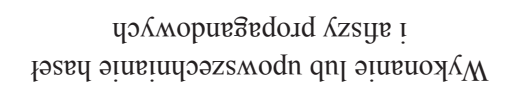 } & 6 & 6 & 6 & 6 & 6 \\
\hline & \multicolumn{2}{|c|}{ 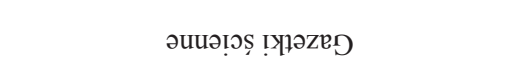 } & $a$ & $\cong$ & $=$ & $\infty$ & $a$ \\
\hline 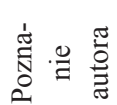 & \multicolumn{2}{|c|}{ 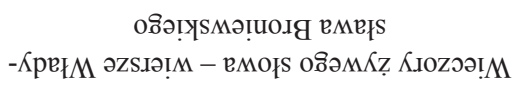 } & $a$ & 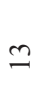 & $\beth$ & $\infty$ & $a$ \\
\hline \multirow{4}{*}{ 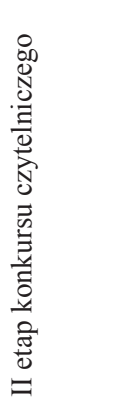 } & \multicolumn{2}{|c|}{ 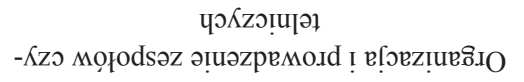 } & $\ddot{n}$ & 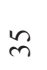 & \& & $\tilde{m}$ & $\dddot{n}$ \\
\hline & \multicolumn{2}{|c|}{ 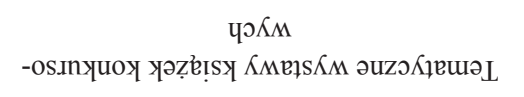 } & $a$ & 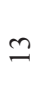 & $\Xi$ & $\infty$ & $a$ \\
\hline & \multicolumn{2}{|c|}{ 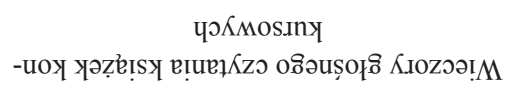 } & $a$ & $\cong$ & $=$ & $\infty$ & $a$ \\
\hline & \multicolumn{2}{|c|}{ 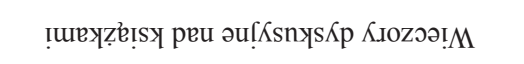 } & $a$ & $\underline{n}$ & $=$ & $\infty$ & $a$ \\
\hline \multirow{2}{*}{ 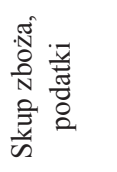 } & \multicolumn{2}{|c|}{ 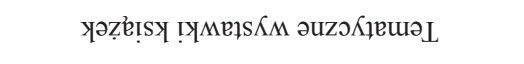 } & $a$ & $\underline{m}$ & $\Xi$ & $\infty$ & $a$ \\
\hline & \multicolumn{2}{|c|}{ 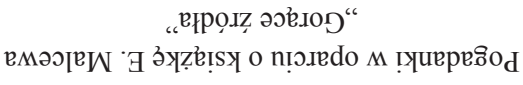 } & $a$ & $\cong$ & $\exists$ & $\infty$ & $a$ \\
\hline 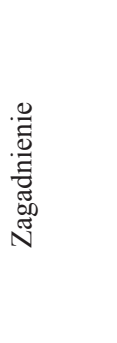 & 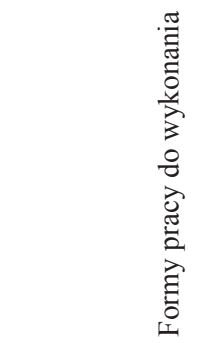 & 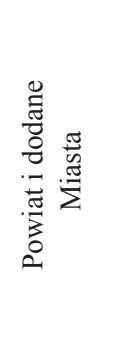 & 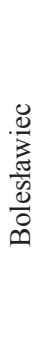 & 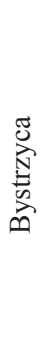 & 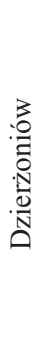 & 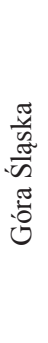 & 离 \\
\hline 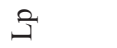 & & & - & $\sim$ & $m$ & $\nabla$ & $n$ \\
\hline
\end{tabular}


Małgorzata Korczyńska-Derkacz

\begin{tabular}{|c|c|c|c|c|c|c|c|c|c|c|c|c|c|c|c|}
\hline ก & $\stackrel{\infty}{q}$ & 8 & $\approx$ & $\approx$ & q & 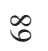 & q & q & F & 8 & $\approx$ & లr & $\forall$ & q & o \\
\hline$\underset{\sim}{2}$ & ¿ & i & $\simeq$ & i & خे & $\stackrel{\infty}{m}$ & ㄱ & ㄱ. & ה & i & $\stackrel{0}{0}$ & $\stackrel{\infty}{-}$ & $\tilde{N}$ & ㄱ. & ิ \\
\hline$\cong$ & $\simeq$ & $\cong$ & $\infty$ & 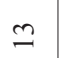 & 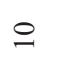 & $=$ & 인 & 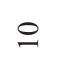 & $=$ & $\cong$ & $\infty$ & $a$ & $=$ & 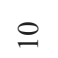 & 은 \\
\hline 0 & 0 & 0 & 6 & 0 & 0 & 0 & 6 & 6 & 6 & 6 & 0 & 6 & 6 & 6 & 0 \\
\hline$\cong$ & $\simeq$ & 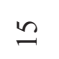 & $\infty$ & $\underline{m}$ & 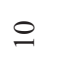 & $=$ & 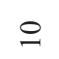 & 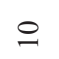 & $=$ & 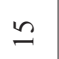 & $\infty$ & $a$ & $=$ & 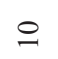 & 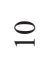 \\
\hline$\cong$ & $\simeq$ & $\cong$ & $\infty$ & 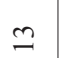 & 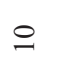 & $=$ & 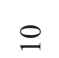 & 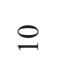 & $=$ & $\cong$ & $\infty$ & $a$ & $=$ & $\cong$ & 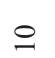 \\
\hline in & in & ig & $m$ & 8 & q & in & q & q & \% & 6 & $\ddot{\sim}$ & q & if & q & if \\
\hline$\cong$ & $\simeq$ & $\cong$ & $\infty$ & 9 & 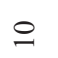 & $=$ & 은 & $ㅇ$ & $=$ & $\cong$ & $\infty$ & $a$ & $=$ & $\circ$ & 인 \\
\hline$\cong$ & $\simeq$ & $\cong$ & $\infty$ & $\cong$ & 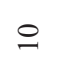 & $=$ & 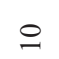 & 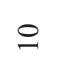 & $=$ & $\cong$ & $\infty$ & $a$ & $=$ & 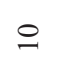 & 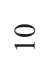 \\
\hline 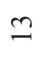 & $\simeq$ & 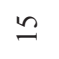 & $\infty$ & 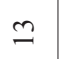 & 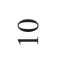 & $=$ & 2 & 으 & $=$ & $\simeq$ & $\infty$ & $a$ & $=$ & 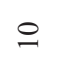 & 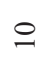 \\
\hline$\cong$ & $\simeq$ & 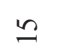 & $\infty$ & 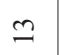 & 으 & $=$ & 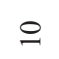 & 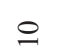 & $=$ & $\cong$ & $\infty$ & $a$ & $=$ & $\cong$ & 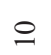 \\
\hline$\cong$ & $\simeq$ & $\simeq$ & $\infty$ & $\cong$ & 인 & $=$ & 은 & 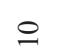 & $=$ & $\simeq$ & $\infty$ & $a$ & $=$ & 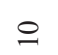 & 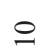 \\
\hline 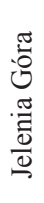 & 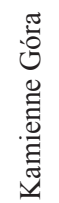 & $\begin{array}{l}\frac{8}{\sqrt{3}} \\
\frac{0}{\Delta}\end{array}$ & 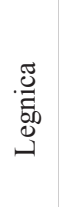 & 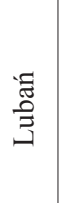 & 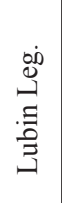 & 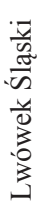 & 总 & 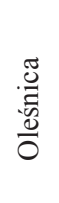 & $\begin{array}{l}\text { 嵒 } \\
\text { d }\end{array}$ & $\begin{array}{l}\stackrel{\Xi}{\mathbb{N}} \\
\stackrel{N}{=}\end{array}$ & 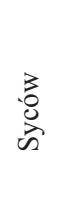 & 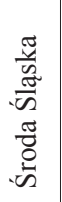 & & 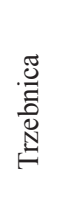 & 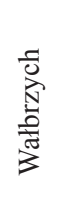 \\
\hline 6 & $r$ & $\infty$ & $a$ & 으 & $=$ & $\simeq$ & 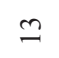 & \pm & $\simeq$ & $\stackrel{0}{\circ}$ & $=$ & $\stackrel{\infty}{ }$ & 2 & ¿ & $\vec{N}$ \\
\hline
\end{tabular}


Popularyzacja książki rolniczej i czytelnictwa fachowego na wsi

\begin{tabular}{|c|c|c|c|c|c|c|c|c|c|c|c|c|}
\hline ల్ల & \& & $\stackrel{\infty}{+}$ & లి & F & $\begin{array}{l}\stackrel{0}{\varrho} \\
=\end{array}$ & $\stackrel{0}{0}$ & $\stackrel{\bullet}{\bullet}$ & $\stackrel{\bullet}{0}$ & ণ & \& & $\stackrel{\infty}{\stackrel{0}{ }}$ & $\underset{\beth}{\stackrel{J}{J}}$ \\
\hline$\stackrel{\infty}{-}$ & ণ & $\stackrel{\nabla}{\sim}$ & $\stackrel{\infty}{-}$ & $\widetilde{\sim}$ & $\begin{array}{l}\infty \\
\stackrel{0}{n}\end{array}$ & $\infty$ & $\infty$ & $\infty$ & 으 & $\stackrel{0}{ }$ & 汸 & त్ర \\
\hline$a$ & $\stackrel{0}{ }$ & $\stackrel{\simeq}{\simeq}$ & $a$ & $=$ & $\underset{\sim}{\tilde{N}}$ & N & $\sim$ & $N$ & $\nabla$ & $\infty$ & $\infty$ & 리 \\
\hline 6 & 0 & 0 & 6 & 0 & $\begin{array}{l}0 \\
\end{array}$ & 0 & 0 & 0 & 0 & 으 & $\dot{m}$ & 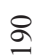 \\
\hline$a$ & $\stackrel{\varrho}{ }$ & $\simeq$ & $a$ & $=$ & $\underset{\infty}{\sim}$ & $\nabla$ & $N$ & $\sim$ & $r$ & 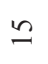 & ㅇ & $\frac{m}{n}$ \\
\hline$a$ & 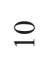 & $\simeq$ & $a$ & $=$ & $\underset{\sim}{\sim}$ & $\infty$ & $\nabla$ & $\nabla$ & $r$ & $\cong$ & $\stackrel{\infty}{n}$ & $\vec{\sim}$ \\
\hline$\ddot{m}$ & \& & $\stackrel{\wp}{f}$ & 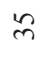 & $\stackrel{\wp}{f}$ & 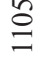 & ' & ' & ' & ' & $\infty$ & $\infty$ & $\stackrel{\varrho}{\Xi}$ \\
\hline$a$ & 으 & $\simeq$ & $a$ & $=$ & $\underset{\sim}{\sim}$ & $m$ & $\sim$ & $\sim$ & $r$ & $\cong$ & Әे & $\frac{N}{m}$ \\
\hline a & 으 & $\simeq$ & $a$ & $=$ & $\underset{\sim}{\tilde{N}}$ & $\nabla$ & $\sim$ & $\sim$ & $r$ & $\cong$ & ㅇ & $\frac{m}{m}$ \\
\hline$a$ & 으 & $\stackrel{工}{\simeq}$ & $a$ & $=$ & $\underset{\sim}{\infty}$ & + & $N$ & $N$ & $r$ & $\cong$ & ్ల & $\stackrel{m}{m}$ \\
\hline$a$ & 으 & $\stackrel{工}{工}$ & $a$ & $=$ & $\stackrel{\widetilde{N}}{\sim}$ & ' & ' & ' & - & $N$ & $m$ & $\underset{\sim}{\sim}$ \\
\hline$a$ & 으 & $\simeq$ & $a$ & $=$ & $\stackrel{\widetilde{N}}{\sim}$ & - & - & - & $N$ & 6 & $=$ & নे \\
\hline$\frac{3}{\frac{3}{0}}$ & $\frac{3}{3}$ & $\begin{array}{l}\frac{0}{3} \\
\frac{0}{0} \\
\frac{0}{N} \\
\text { N }\end{array}$ & $\begin{array}{l}\frac{8}{0} \\
\stackrel{N}{0} \\
\text { D. } \\
N\end{array}$ & $\begin{array}{l}\frac{\pi}{3} \\
\frac{0}{0} \\
\frac{0}{N}\end{array}$ & 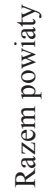 & 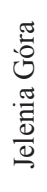 & 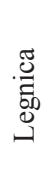 & 晜 & 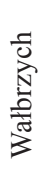 & 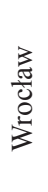 & 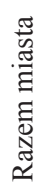 & $\begin{array}{l}\text { है } \\
\text { :. } \\
0 \\
0\end{array}$ \\
\hline$\widetilde{\approx}$ & $\hat{\imath}$ & $\stackrel{ \pm}{\sim}$ & $\sqrt{2}$ & iे & & & & & & & & \\
\hline
\end{tabular}


Małgorzata Korczyńska-Derkacz

\begin{tabular}{|c|c|c|c|c|}
\hline 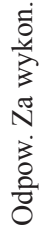 & 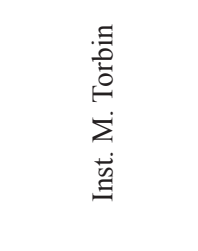 & $\underline{3}$ & 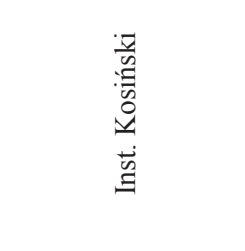 & 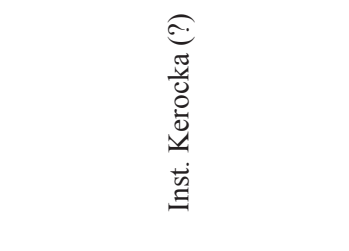 \\
\hline 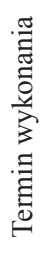 & $\begin{array}{l}\dot{n} \\
n \\
\dot{x} \\
\dot{0} \\
\dot{m}\end{array}$ & $\begin{array}{l}n \\
\hat{x} \\
\dot{x} \\
\dot{n}\end{array}$ & $\begin{array}{l}n \\
n \\
\dot{\bar{x}} \\
n \\
n\end{array}$ & 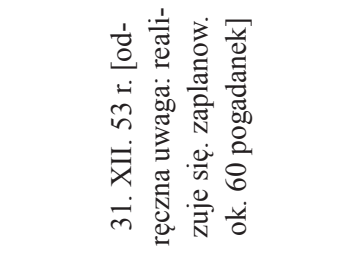 \\
\hline 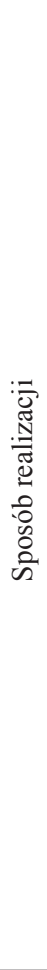 & 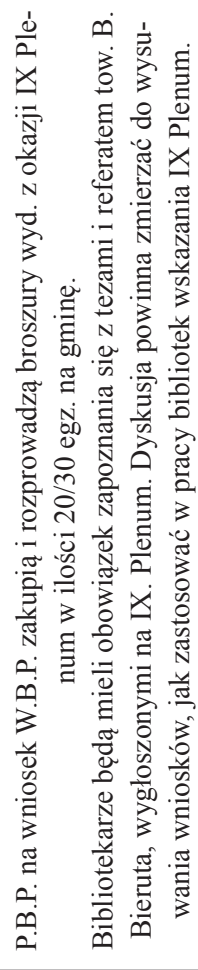 & 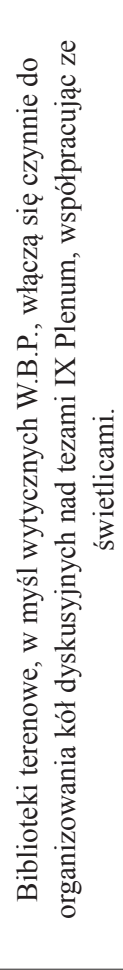 & 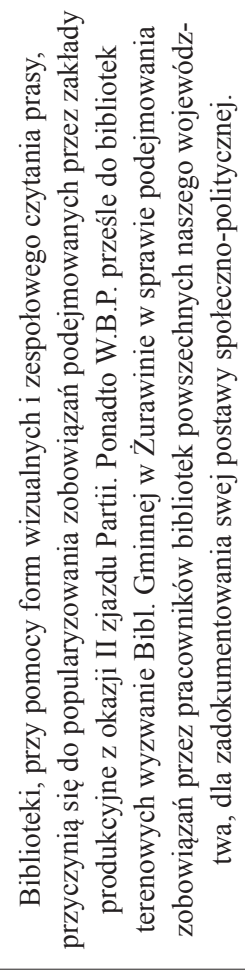 & 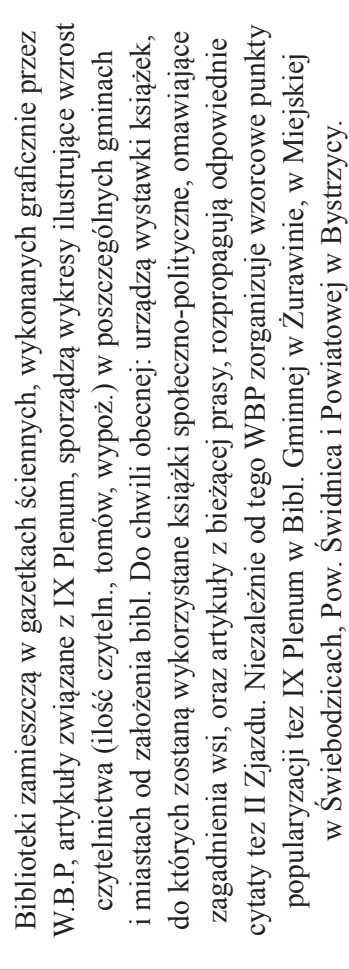 \\
\hline 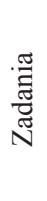 & 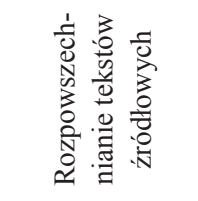 & 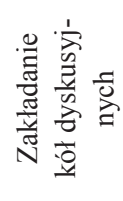 & 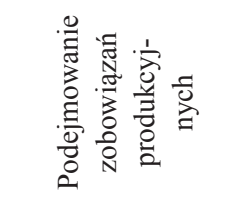 & 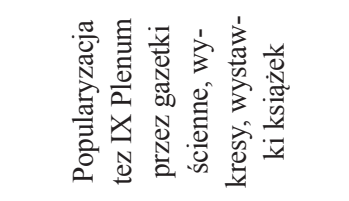 \\
\hline$\dot{\imath}$ & - & i & $\dot{m}$ & $\dot{\nabla}$ \\
\hline
\end{tabular}




\begin{tabular}{|c|c|c|}
\hline 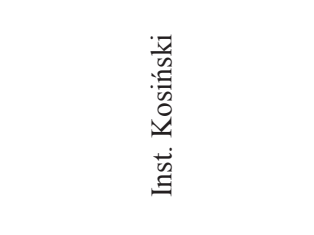 & 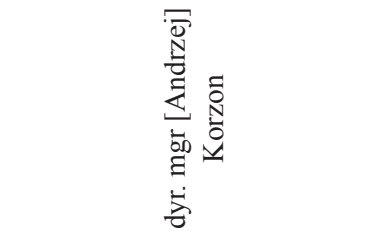 & \\
\hline 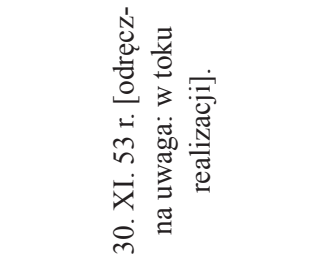 & 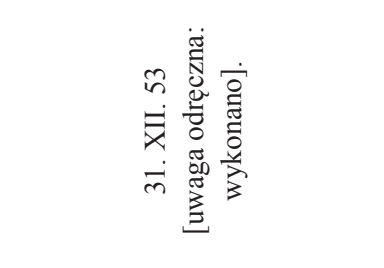 & 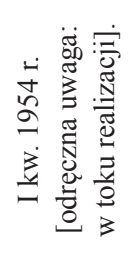 \\
\hline 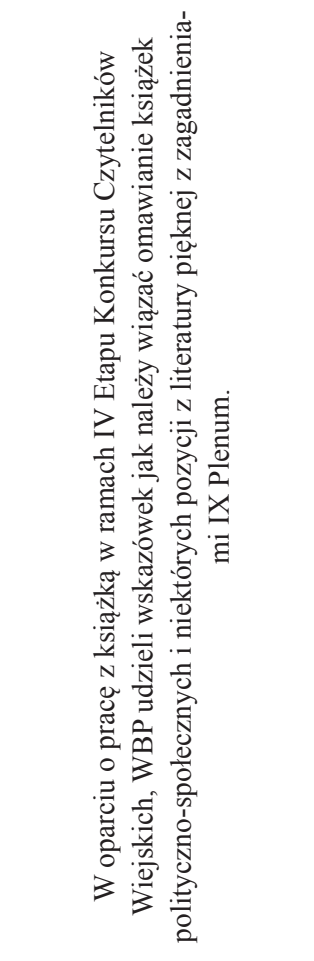 & 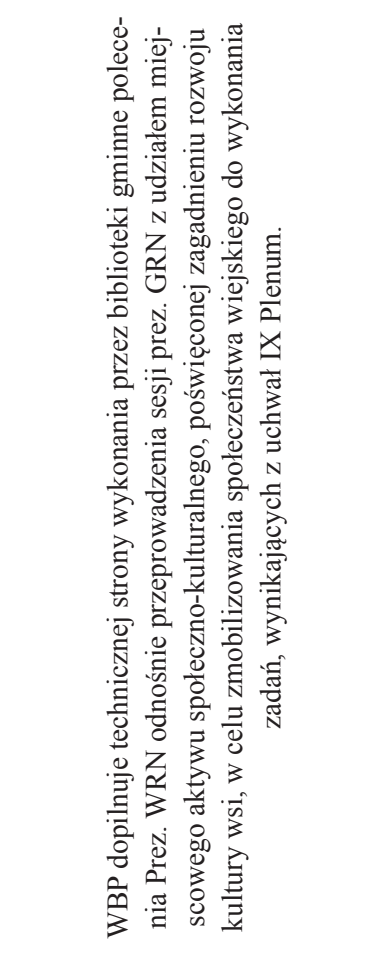 & 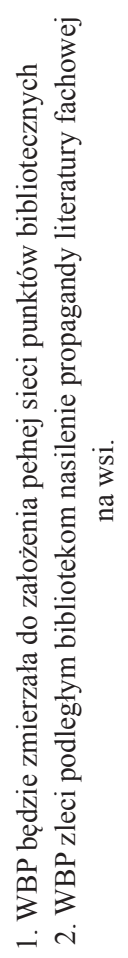 \\
\hline 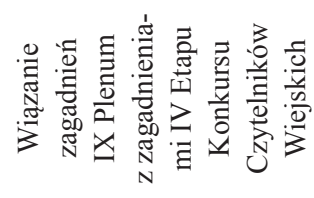 & 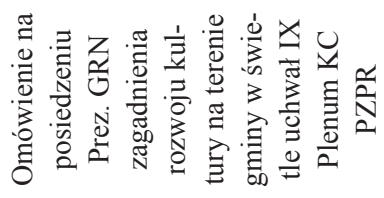 & 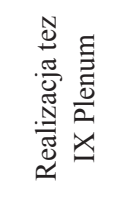 \\
\hline$\dot{n}$ & $0^{\circ}$ & $\therefore$ \\
\hline
\end{tabular}


Uzupełnieniem tych danych są liczby podane w „Sprawozdaniu z udziału placówek czynnego upowszechnienia kultury w realizacji tez przedzjazdowych" z 1 III 1954 r., które zawiera plany dotyczące całego Wydziału Kultury. Miał on w 13 Domach Kultury na terenie województwa zorganizować: 15 zespołów teatralnych, 9 chóralnych, 11 muzycznych, 9 tanecznych, 7 plastycznych, 13 redakcyjnych gazetek świetlicowych, 12 zespołów Upowszechnienia Wiedzy Rolniczej oraz 3 kółka miczurinowskie. W 88 świetlicach wzorcowych plan ten przewidywał działalność tyluż zespołów czynnych, 60 chóralnych i tylko 7 zespołów muzycznych, ponieważ ich istnienie uzależnione było od liczby posiadanych instrumentów muzycznych. Planowano powołanie 56 zespołów tanecznych, 13 plastycznych, 44 brygad agitacyjnych, 88 zespołów redakcyjnych gazetek świetlicowych, 39 zespołów wszechnicy radiowej, 88 zespołów Upowszechnienia Wiedzy Rolniczej, tyle samo kółek samokształceniowych i 15 kółek miczurinowskich; zakładano zorganizowanie 54 kursów nauki języka rosyjskiego. Odnośnie do bibliotek w ,Sprawozdaniu” czytamy:

Na podstawie nadesłanych meldunków z terenu oraz wyjazdów służbowych pracowników

Wydziału [...] biblioteki terenowe przeprowadzily na przestrzeni 3 miesięcy 598 pogadanek w 207 placówkach. Tematyka przeprowadzonych odczytów i pogadanek to zagadnienie

IX Plenum KC PZPR oraz tezy przedzjazdowe. Ponadto przeprowadzono w miesiącach grudzień i styczeń 131 odczytów wygłoszonych przez prelegentów TWP ${ }^{30}$.

Planowano przygotowanie 2000 gazetek przyjmując na jedną bibliotekę gminną i miejską rocznie cztery gazetki - z okazji ważnych uroczystości lub rocznic jak np. w rocznicę śmierci Włodzimierza Lenina i Józefa Stalina, Międzynarodowego Dnia Kobiet, 1 Maja, PKWN, rewolucji październikowej lub na tematy aktualnych zagadnień politycznych i gospodarczych. Wystaw okolicznościowych miano zorganizować ok. 2500, a zajęć z czytelnikami ok. 2000, przyjmując - także i tu - na jedną bibliotekę miejską i gminną ok. cztery imprezy rocznie ${ }^{31}$.

Wyjazdów terenowych, mających zapewnić pomoc instruktorską zaplanowano aż 3920, a kierowano ją zwłaszcza do bibliotek gminnych. Nie oznacza to, że nie odnotowywano żadnych problemów. W jednym ze sprawozdań czytamy:

Współczynnikiem hamującym w bardzo poważnym stopniu rozwój działalności kulturalno-oświatowej jest nieustająca fluktuacja kadr kulturalno-oświatowych. I tak w ciągu 1953 r. w 16-tu powiatach nastąpiła zmiana Kierownika Oddziału Kultury w trzech

30 APWr., PWRN, Wydział Kultury, sygn. IX/25, Sprawozdanie z udziału placówek czynnego upowszechnienia kultury w realizacji tez przedzjazdowych z 1 marca 1954, k. 79-80.

31 Tamże, Sprawozdanie Prezydium Wojewódzkiej Rady Narodowej z działalności placówek kulturalno-oświatowych na terenie województwa wrocławskiego, k. 61. 
wypadkach jednokrotnie, a w 11-tu wypadkach dwukrotnie, a w 2-ch wypadkach nawet trzykrotnie ${ }^{32}$.

W sprawozdaniach ,z terenu” najczęściej narzekano na brak kierownictwa politycznego w pracach kulturalnooświatowych, brak ,aktywu” przygotowanego do pracy bibliotecznej. Rzeczywiście, prace w zakresie upowszechniania wiedzy rolniczej często prowadzili ludzie do tego nieprzygotowani, np. w sprawozdaniu z gromady Zajączków w gminie Oborniki Śląskie czytamy:

Prócz zespołów czytelniczych na gromadzie prowadzone jest przez sołtysa gromady szkolenia w zakresie upowszechnienia wiedzy rolniczej; frekwencja na powyższym szkoleniu jest bardzo nikła, gdyż przeciętnie uczęszcza 5 uczestników ${ }^{33}$.

I w innym miejscu:

Jedną z poważnych akcji przeprowadzonych na odcinku umasowienia czytelnictwa jest przebiegający IV Etap Konkursu Czytelniczego Bibliotek Wiejskich, w którym to na odcinku werbunku uczestników województwo Wrocław wzięło I miejsce w skali ogólnopolskiej - uzyskując 51586 zgłoszonych uczestników, co stanowi 174,6\% planu Centralnej Komisji Konkursowej. Cyfry te, to osiągnięcia bibliotek terenowych, ze strony organizacji współdziałających w przebiegającym konkursie, jak też placówek czynnego upowszechnienia kultury - gminnych świetlic wzorcowych i Domów Kultury pomoc bibliotekom terenowym jest bardzo znikoma. Wypłynęło to m.in. z przyczyn niedostatecznego stawiania tych spraw przed pracownikami resortu kultury (z wyłączeniem pionu bibliotek) ${ }^{34}$.

Analiza danych zamieszczonych w cytowanych sprawozdaniach oraz towarzyszących im zestawieniach pozwala stwierdzić, że przewidziane do realizacji zadania były zgodne z ogólnokrajowymi wytycznymi i że wszystkie możliwe formy pracy zostały przez biblioteki uwzględnione. Wyraźnie obecna jest w nich - jak pisał Dariusz Jarosz - „magia wielkich liczb”35. Musimy jednak pamiętać, że ówczesna sprawozdawczość rządziła się swoimi prawami i że potwierdzenia przytaczanych w nich danych zapewne należy szukać dalej, być może w archiwach centralnych. Zarówno Biblioteka Wojewódzka, jak też biblioteki niższych szczebli dążyły do jak najszerszej popularyzacji referatu Bieruta i wynikających z niego tez przedzjazdowych. Materiały źródłowe (referat, tezy) kupowały biblioteki wszystkich szczebli, a następnie omawiano je na spotkaniach terenowych kół dyskusyjnych. Wspólnie organizowano pogadanki, odczyty, dyskusje nad książką, opracowywano gazetki ścienne i „,błyskawice”, działały Koła Wszechnicy Radiowej. W sprawozdaniach z województwa wrocławskiego pojawiały się także

\footnotetext{
32 Tamże, k. 56.

33 Tamże, Sprawozdanie z Gromady Zajączków gm. Oborniki Śląskie pow. Trzebnica, k. 12.

34 Tamże, Sprawozdanie Prezydium Wojewódzkiej Rady Narodowej z działalności..., k. 61.

35 D. Jarosz, dz. cyt., s. 298.
} 
informacje o organizowaniu bibliotek sąsiedzkich i o ksiegonoszach, którzy dostarczali książki zainteresowanym. Bibliotekarze starali się, aby wszystkie podejmowane działania przekraczały zakładane normy znacznie ponad $100 \%$, a oni sami godni byli miana ,żołnierzy rewolucji kulturalnej”.

\section{Bibliografia}

Archiwalia:

Archiwum Państwowe we Wrocławiu, Zespół PWRN, Wydział Kultury, sygn. IX/25.

Źródła opublikowane:

Bibliotekarze w dyskusjach przedzjazdowych, „Poradnik Bibliotekarza” 1953, nr 12, s. $265-272$.

Jagusztyn W., Koleżanko! Kolego!, „Poradnik Bibliotekarza” 1953, nr 12, s. 269-272.

Konkurs Czytelników Wiejskich IV etapu: 22.VII.1953-22.VII.1954, „Poradnik Bibliotekarza" 1953, nr 9, s. 198-199.

List Walnego Zjazdu Delegatów SBP do Prezesa Rady Ministrów Bolesława Bieruta, „Bibliotekarz” 1954, nr 1, s. 2-3.

Łukaszewska R., Jak dobierać książki do czytania w Konkursie Czytelników Wiejskich, „Poradnik Bibliotekarza” 1953, nr 11, 241-251.

Odpowiedzialne zadania bibliotekarzy polskich po IX Plenum KC PZPR. Przemówienie Wiceministra Kultury i Sztuki Stanisława Piotrowskiego na Zjeździe Delegatów SBP w dniu 19 grudnia 1953 r., „Bibliotekarz” 1954, nr 1, s. 3-4.

Nasze zadania na tle IX Plenum, „Poradnik Bibliotekarza” 1954, nr 1, s. 1-6.

Stowarzyszenie Bibliotekarzy Polskich, „Bibliotekarz” 1954, nr 1, s. 1-2.

Zadania partii $w$ walce o szybsze podniesienie stopy życiowej mas pracujacych $w$ obecnym okresie budownictwa socjalistycznego. Referat przewodniczacego KC PZPR towarzysza Bolesława Bieruta wygłoszony na IX Plenum KCPZPR, „Nowe Drogi” 1953, nr 10, s. 5-40.

Opracowania:

Jarosz D., Codzienna mobilizacja. O propagandzie czytelnictwa książek w Polsce stalinowskiej i trudnościach jej badania, „Z Badań nad Książką i Księgozbiorami Historycznymi” 2011, t. 5, s. 295-305. 